\title{
THE ANTI-TRUST LAWS AND THE REGULATION OF PRICE COMPETITION
}

\author{
Arthur Robert Burns*
}

\section{The Principle of the Sherman Law}

Direct social control of the industrial system presents dismaying difficulties and dangers. The National Recovery Administration revealed the complexity of the economic problems that arise when conflicts of self interest are replaced by direct governmental planning. The political consequences of a high concentration of economic power in the state are less clear but no less disquieting. Efforts to meet the growing criticism of the industrial system while avoiding these difficulties and dangers $^{1}$ have taken a peculiar form in the United States. An effort has been made to preserve by law the conditions necessary for the continuance of competition. If the prerequisites of competition could be preserved detailed controls of industrial policy would, it was hoped, be avoided. Direct appraisal of the treatment of the buyer would be unnecessary. Experience of this policy has, however, revealed the difficulty of giving specific meaning to the comfortable phrase of the economists, "assuming free competition." It has brought disillusionment because of the increasingly wide divergence of actual business conditions from the free competition of economic theory. In consequence social policy shows signs of transformation into a policy of regulating an admittedly imperfectly competitive world.

The prerequisites of competition have recently been reëxamined by economists and prove to be very difficult of attainment. There must be a perfect market in the sense that, in the absence of general changes in the conditions of demand and supply, a slight reduction in price by one firm would shift all business in the market to that firm. Buyers may have no loyalties to sellers or preferences for the product of any one of them and they must be exceedingly well informed. Sellers must be sufficiently numerous for none of them to find it profitable to take account of the effect of changes in his output upon the market price.

B.Sc. (Econ), I920; Fh.D., 1926, University of London. Assistant Professor of Economics, Faculty of Political Science, Columbia (iniversity. Author of The Decline of Competition (1936).

1 (Entralized control of nonetary policy has been increasingly relied upon curing the present century to provide a broad control of the industrial system without direct and detailed interference with initiative. Marriner S. Eecles, Chairman of the Federal Reserve System, has now, however, declared that the Federal Reserve System is powerless to maintain a stable economy unless other essentially non-monetary factors neceasary to stability are brought into line either by private interests or the government. Statement in N. Y. Times, March 16, 1937, p. 9. 
The Sherman Act, ${ }^{2}$ the first federal anti-trust law, was passed in response to evidence that business was evolving away from these conditions. Market control had been obtained in some industries by the concentration of a large proportion of the business in single firms. In others, firms had become sufficiently few to get together in pools and agree upon prices. Two major explanations of these tendencies were possible. On the one hand, they might be attributed to changes in technology. Business men competing with each other in the effort to utilize the most economical methods of production had developed firms large enough to make it necessary for them to take account of their power over the market price. Where goods are costly to transport the markets of firms are not nationwide; even where there are many firms in the country as a whole there may be few in each local market. This explanation suggests that competition has in fact frequently proved to be self-destructive. Efforts to maintain the prerequisites of competition in these circumstances would not yield the fruits of competition which are the ultimate objective of social policy. If large firms are the most economical, any limitation, direct or indirect, upon opportunities to attain the most economical size hamper the initiative of individuals and obstruct the utilization of the most economical methods of production.

The alternative explanation of the declining numbers of firms is that they have increased in size by resort to tactics which have little relation to their economies in production. This interpretation of the events between the Civil War and I8go suggested changes in law to prevent resort to these practices. Only the fittest would then survive and they would be numerous enough to satisfy the requirements of competition. Such appears to be the basis of the Sherman Law. It raises the question why a moral lapse should have occurred soon after the Civil War, and suggests to the enquiring mind the possibility that it may have been connected with the revolution in methods of transportation which widened markets and facilitated the utilization of large scale methods of production. Drastic methods were undoubtedly used, but they may have been due to the great economies in production methods then made available if rapid industrial concentration could be effected. The survival of large firms since that time and the rise of others suggest that they have maintained themselves either because of superior efficiency or because of continued buccaneering tactics. Either the Sherman Law has failed as a means of eliminating these tactics or the economies of large scale production have been very important. But with the latter conclusion we return to the first explanation of the decline of the competitive market.

\section{Price Competition under the Sherman Act and Federal Trade Commission Acts}

\section{A. Price Policies}

The attempt by law to preserve the competitive market was expressed in a condemnation of contracts, combinations or conspiracies in restraint of interstate commerce. Monopolizing, or attempting to monopolize, or combining or conspiring

26 StaT. 209 (1890), 15 U. S. C. $\$ 5$ I-7. 
to monopolize any part of interstate commerce was similarly declared illegal. By the courts "it has repeatedly been held ... that the purpose of the statute is to maintain free competition in interstate commerce." 3 Behind the assumptions of free competition by the economists lay an assumption of the existence of private property. Congress was faced with the problem of writing a commercial code determining the precise set of rights and duties which would constitute the kind of private property necessary to produce the results of competition. By the vague wording of the statute it passed this problem to the courts. In the course of their efforts to solve the problem they were presented with the question whether certain price policies were in violation of the assumption of free competition. They have consistently refused to appraise price policies in terms of profits. Had they not taken this position they would speedily have been involved in the regulation of prices and the problems presented by such regulation in the industries which they have decided to be affected with a public interest. They have, however, sought to test price policies in terms of the intentions of the parties. An intent to drive out a rival is evidence of attempts to restrain trade or create a monopoly. ${ }^{4}$ The basic difficulty of this policy lies in the, vagueness and even inappropriateness of the criterion of intent. In times when speedy concentration of industry is induced by recognition of the economies of large scale production price cutting tactics may be drastic enough to persuade the court that it smells an evil intent. But the attainment of the economies of mass production may be the ultimate inducement to adopt such policies. Not all buccaneering tactics can be excused on this basis but the touchstone used by the court does not distinguish the vigorous pursuit of the economies of size from the vigorous pursuit of monopoly profits.

The policy of the courts tends to encourage the attainment of the economies of production by other methods than price cutting. In general they have been unwilling to interfere with mergers or to break up very large firms. ${ }^{5}$ The smaller firms instead of being driven out tend to be bought out with consequent advantage to their owners but not necessarily to the consumer. ${ }^{6}$ Concentration has, therefore, not been prevented and price behavior in sharp contrast with that in the competitive market has appeared. "When the courts have been presented with evidence of such

${ }^{8}$ American Column and Lumber Co. v. U. S., 257 U. S. 377, 400 (1921). Cf. "The theory of the anti-trust laws in their modern orientation is that, in the absence of adequate governmental control upon a monopolistic basis, the influence of government should be exercised to keep the markets free to all on a competitive basis." McLaughlin, Legal Control of Competitive Methods (1936) Iowa L. Rev. 302.

"The price wars in the tobacco industry were regarded as contributory evidence of intent to monopolize. U. S. v. American Tobacco Co., 221 U. S. 106 (IgII). The intent of the Corn Products Refining Company to monopolize was inferred in part from sales below cost and the company was forbiaden to resort to low price campaigns. U. S. v. Corn Products Refining Co., 234 Fed. 964 (S. D. N. Y. 1916). The Stcel Corporation was held to be a "good trust" partly because it had not indulged in secret price cutting. U. S. v. U. S. Steel Corp., 251 U. S. 417 (1920). The contention that the International Harvester Company had not used its power to restrain trade was supported by the claim that it had not reduced prices below cost for the purpose of driving out competitors. U. S. v. International Harvester Co., 274 U. S. 693 (1927).

${ }^{s}$ Even where firms have been broken up the number in the market has frequently remained small.

- Cf. Burns, The Process of Industrial Concentration (I933) 47 Q. J. EcoN. 277. 
contrasts they have not regarded it as evidence of the failure of the policy of maintaining the prerequisites of competition. The Supreme Court dismissed with brusque contempt.evidence that the price of steel rails had been stable for many years, ${ }^{7}$ and in the same case it declared that "the law does not make mere size an offence." Likewise it has held that price leadership "does not establish any suppression of competition or show any sinister domination."

The policy of maintaining the prerequisites of competition by the control of industrial practices also provides the foundation of the Federal Trade Commission Act. ${ }^{10}$ This act empowered the Federal Trade Commission to prevent unfair methods of competition. The Commission has also made a few, but none too successful, attempts to deal with price policies regarded as unfair. Apart from the cases concerning price discrimination which were taken under the authority of both the Clayton $^{10^{2}}$ and Federal Trade Commission Acts it has made little progress in establishing a criterion of fairness in price policies. It ordered a large distributor to cease selling sugar at a loss during the war, the sales being in combination with other sales, but it was not upheld by the court. ${ }^{11}$ It ordered a seller to cease selling at less than the price charged by a rival on the ground that the price was not set in good faith. ${ }^{12}$ The acceptance by the Commission in I928 and I929 of Trade Practice Conference rules against less than cost selling indicates pressure for such rules and the willingness of the Commission to condemn the practice. ${ }^{13}$

\section{B. Cooperative Control of Prices or Output}

Agreements between sellers concerning prices and output have generally been condemned without regard for the reasonableness of the policy pursued. The Supreme Court has stated that it would hesitate, in the absence of express legislation, to make the difference between legal and illegal business relations "depend upon so uncertain a test as whether prices are reasonable-a determination which can be made only after a complete survey of our economic organization and a choice between rival philosophies."14 Nevertheless, some six years later the Court retired from this position and decided that "the mere fact that the parties to an agreement eliminate

${ }^{7}$ U. S. v. U. S. Steel Corp., 25 I U. S. 417 (1920).

${ }^{8} \mathrm{Id}$. at $45 \mathrm{I}$.

${ }^{\circ}$ U. S. v. International Harvester Co., 274 U. S. 693 , 709 (1927).

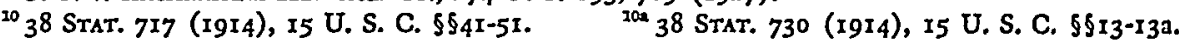

${ }^{11}$ F. T. C. v. Sears Roebuck \& Co., I F. T. C. 163 (1918), 258 Fed. 307 (C. C. A. 9th, 1919). The court held that the Commission had no power to proceed against sales below cost but that misrepresentation in connection with such sales was illegal.

${ }^{13}$ F. T. C. v. The Oakes Co., 3 F. T. C. 36 (1920).

${ }^{3}$ Nat. Industrual Conf. Bd., The Public Regulation of Competitive Practices (1925) 64. In both policy and form of administration the Commission anticipated the subsequent National Recovery Administration.

${ }^{16}$ U. S. v. Trenton Potteries Co., 273 U. S. 392, 398 (1927). "The power to fix prices, whether reasonably exercised or not, involves power to control the market and to fix arbitrary and unreasonable prices." Id. at 397. Conditions may change and a price once reasonable may be maintained and become unreasonable. If power to fix prices depended upon tha reasonableness of the prices the government, in enforcing the Sherman Law, would be compelled to shoulder the "burden of ascertaining from day to day whether it has become unreasonable through the mere variation of economic conditions." Id. at 398. 
competition between themselves is not enough to condemn it."15 The Court took into account the peculiar nature of the bituminous coal industry, its excess capacity, its difficulties in meeting the competition of oil, gas, and water power, and its "chaotic condition." "The fact that the correction of abuses would lead to fairer price levels does not mean that abuses should go uncorrected or that cooperative endeavor to correct them necessarily constitutes an unreasonable restraint of trade." 16 The establishment of a cooperative selling agency including a large number of the sellers in one field was held, therefore, not to be illegal. But the Court provided that the case should remain open so that evidence of any attempt by the agency to abuse its position might be brought before it. Apparently in this case the Court, interpreting the Sherman Act, has embarked upon a journey towards the control of prices, although that control is indirect and tentative.

\section{Resale Price Maintenance}

During the past decade the courts have been called upon to decide whether a seller may, without contravening the Sherman or Federal Trade Commission Acts, control the price at which his product is resold by the buyer. The very existence of the problem on a scale stimulating litigation is an indication that the prerequisites of competition have not been preserved on the selling side of the market. In fact the imperfections of competition between sellers have been tacitly accepted and policy has been framed partly in terms of the forms of business organization and partly in terms of the control of the policies of sellers in imperfect competition with each other in the hope of maintaining the prerequisites of competition at the next stage in the distributive process. Decision in terms of forms of organization has, however, enfeebled efforts by manufacturers to maintain competition at the next stage by restricting them to a variety of not entirely effective methods. At this next stage, however, there has been in process a reorganization which has threatened with expulsion small scale distributors and their suppliers. These threatened groups have recently induced legislation giving more effective power to manufacturers of branded consumer goods to preserve the lives of small scale distributors. Thus the imperfection of competition at one stage is not only accepted but utilized with the object of maintaining the number of distributors. The control of the organization of distribution is coming, therefore, to rest partly in the hands of manufacturers.

The efforts of the courts to rest their decisions upon legal forms rather than economic consequences are indicated in a brief series of cases. Contracts providing for price maintenance are held to be contrary to the Sherman Law because they restrain trade between the buyers. ${ }^{17}$ The same result is beyond the reach of the law if the manufacturc: merely urges retailers to maintain suggested prices, announces that dealers failing to maintain these prices will be denied supplies and

${ }^{25}$ Appalachian Coals Inc. v. U. S. 288 U. S. $344,3^{60}$ (1933).

${ }^{16}$ Id. at 374 .

${ }^{17}$ Dr. Miles Medical Co. v. Park \& Sons Co., 220 U. S. 373 (IgII); Bauer et Cie. v. O'Donnell, 229 U. S. I (1913). 
requests information concerning price cutters. ${ }^{18}$ Keeping records concerning the behavior of dealers and employing systematic devices for detecting price cutting have been held to approach so nearly in effectiveness to contractual covenants eliminating price competition between dealers as to contravene the Federal Trade Commission Act. ${ }^{18}$ But when the dealer is constituted an agent of the manufacturer, the latter is left free to control the resale price without contravening the law. ${ }^{20}$

The constitutionality of legislation specifically authorizing manufacturers to set minimum resale prices has recently been affirmed by the Supreme Court. ${ }^{21}$ The decision rests upon the contention that the distributors owned the commodity but not the brand name. They were free to sell the commodity without identifying labels or containers at any price they chose (not a very real alternative). Whether price cutting in the sale of trademarked products was injurious to the goodwill of the producer was "fairly open to differences of opinion" but if states decided that goodwill was thus damaged the method of protection selected was not unconstitutional. ${ }^{22}$

The imperfection of competition among manufacturers rests largely upon the use of advertising to break up the market into a series of submarkets. Each of these submarkets is occupied by one manufacturer and separated from other submarkets by the preferences of buyers for one product rather than another. The absence of such advertising is, therefore, one of the prerequisites of competition. The sellers of unbranded goods in competition are powerless to exact the maintenance of resale prices. The decision of the Court indicates, however, that it realizes that laws permitting resale price maintenance encourage the building up of goodwill by adver-

${ }^{18}$ U. S. v. Colgate \& Co., 250 U. S. 300 (1919); U. S. v. Schraders Sons, Inc,, 252 U. S. 85 (1920).

${ }^{29}$ Beech Nut Packing Company v. F. T. C., 257 U. S. 44 I (1922); Cream of Wheat Co. v. F. T. C., I4 F. (2d) 40 (C. C. A. 8 th, I926).

${ }^{50}$ U. S. v. General Electric Co., 272 U. S. 476 (I926). The Court seeks, however, by examination of the contracts, to ensure that a genuine agency is established. Standard Fashion Co. v. Magrane Houston Co., 258 U. S. 346 (1922); Butterick Co. v. F. T. C., 4 F. (2d) 910 (1925), cert. denied, 267 U. S. 602 (1925). Cf. Burns, The Decline of Competition (1936), 420.

${ }_{29}$ Old Dearborn Distributing Corp. v. Seagram-Distillers Corp., 57 Sup. Ct. I39 (1936). The state of Illinois had passed a "Fair Trade Act" providing that no contract for the sale or resale of branded goods in "fair and open competition with commodities of the same general class produced by others" should be illegal because it contained either of the following provisions: (a) That the buyer would not resell except at a price stipulated by the seller; (b) That the product should not be further resold except at a price stipulated by the producer or first purchaser. Such provisions in any contract were, by the Act, decmed to imply that the commodity might be sold without reference to the contract in three situations, viz., (1) When the owner of the commodity was closing out his stock "for the purpose of discontinuing delivery of any such commodity" provided that the stock was offered to the manufacturer at the original invoice price at least ten days before its sale to the public; (2) When goods were damaged or deteriorated and the public was so informed; (3) When they were sold by an officer acting under the authority of any court. The Act further prohibited wilfully and knowingly offering for sale or selling any commodity at less than the price stipulated "in any contract" pursuant to the above provisions of the Act whether or not the person so advertising or selling was a party to the contract. The Act did not authorise contracts between producers, between wholesalers or between retailers as to sale or resale prices.

${ }^{\infty}$ It was contended on behalf of the dealer that he had been deprived of the right to dispose of his property at any price he might choose. The court blandly replied that, while there would have been constitutional objection to the annexation by the state of this right to fix the price, there was none when the right was transferred from dealer to manufacturer under legislative sanction. 
tising. In supporting resale price maintenance state governments and the courts are, therefore, departing from the traditional policy of maintaining competition. They are facilitating the replacement of price competition among manufacturers by competition in advertising.

The struggle between large and small scale organization of distribution has taken the form partly of price competition. The large scale distributors desire freedom to cut resale prices as they may choose. The small scale retailers and their suppliers desire the maintenance of margins that will enable them to survive. If they organize and apply pressure to manufacturers the latrer must choose between the large and the small distributors. But the manufacturers are not impartial in this choice. They advertise partly because they are anxious to keep in their own hands some control over the promotion of the sales of their product. They are also fearful of the emergence of small numbers of large distributors who may overpower them. The net outcome of this situation is, therefore, likely to be that manufacturers will endeavor to maintain large numbers of small distributors. By doing so they may prevent the reorganization of distribution upon what may be a more economical basis. High cost distribution, in the form of too many too small outlets, may survive in the interests both of manufacturers and of those threatened with expulsion by the larger firms. Manufacturers are, however, faced with the possibility that the large distributors will establish brands of their own or that they will evade resale price maintenance by combination sales or trade-ins.

The argument that increases in the size of firms are due to unfair practices has arisen in the course of the struggle between large and small distributors. Although resale price maintenance laws go far beyond the exclusion of "loss leaders" these leaders are frequently used as the main justification for the law. "Loss leaders" are condemned by manufacturers who promote their product by advertising. They are irked by the fact that the large distributors find it more profitable to reduce the resale prices of well advertised commodities especially if they have a stated price (e.g., books) than to use other articles as loss leaders. Buyers can make a simple and direct comparison between the cost of the branded goods at large and small stores. Where goods vary in quality and style comparison is a task usually beyond the powers, or even the time, of the retail buyer. By using advertised products as loss leaders large distributors gain a reputation for general low prices more quickly and cheaply than by cutting all prices. Loss leaders may, therefore, be a means of deceiving the buyer into an unjustified belief that a particular store is a cheap store.

In so far as distributors recover a smaller mark-up on loss leaders than on other merchandise there may be price discrimination, although it is discrimination between groups of buyers. Whether or not it constitutes discrimination in fact depends upon the possibility of discovering the correct distribution of the cost of operating a store between dealings in different products and this is an almost impossible task. ${ }^{23}$

\footnotetext{
${ }^{*}$ Fast moving items like loss leaders can, of course, be handled for a smaller mark-up than slow moving ones without reduction of profit.
} 
Where the dealer handles the product without any mark-up or even resells at a price less than he pays discrimination is undeniable. The dealer argues that this policy is an alternative to advertising and can properly claim that, unlike almost all other forms of advertising, it results in direct gains to the consumer. Moreover, in so far as his policy is deceptive, it can hardly be placed upon a lower plane than a great deal of advertising, most of which raises costs while loss leaders reduce prices. Loss leaders can also be attacked because they represent a temporary policy. Distributors are apt to turn for loss leaders from one product to another. The manufacturer claims that there is no economy in these temporary dislocations of his machinery for distribution. Smaller dealers are discouraged from handling the product during the period of price cutting and when the large distributors have turned to some other product good relations must be rebuilt and expenditure incurred for the purpose.

Thus the code of law aimed at the preservation of the prerequisites of competition is being transformed into one giving to manufacturers in imperfect competition with each other the power to control distribution during a period of reorganization. Within the past four years, legislatures in some thirty-one states have accepted this policy and are at the same time endorsing the advertising that gives the manufacturers their power to set resale prices. The Supreme Court has merely taken the view that if legislators are so disposed their actions are not unconstitutional.

\section{Price Discrimination}

\section{A. The Shift from the Preservation of Competition between Manufacturers to the Control of their Prices}

Local and other price discriminations were among the practices of which the early trusts were accused. They were appraised by the courts as evidence of the intent of the seller. This approach has already been discussed. In I9I4, however, legislative prohibitions upon price discrimination were enacted in Section 2 of the Clayton Act, ${ }^{24}$ which has now been replaced by the Robinson-Patman Act of $1936 .{ }^{25}$ In part this legislation suggests an elaboration and clarification of the Sherman Act. But these laws go beyond the effort to preserve the prerequisites of competition among manufacurers. They seek to avoid unfair discrimination between distributors. They rest, therefore, like resale price maintenance laws, upon the admitted hopelessness of maintaining anything like perfect competition among manufacturers. The effort to control differentials in price to buyers of different classes rests broadly upon an attempt to adjust the prices of manufacturers to what they might be assumed to be if there were price competition between the sellers. Failure to prohibit price discrimination between ultimate consumers suggests, however, that the old principle lives on. ${ }^{26}$ It is hoped to preserve competition among dis-

* Supra note $10^{2}$.

$\approx_{49}$ STAт. 1526 (1936), 15 U. S. C. $\$ \$ 13,13 a, 13 b, 21 a$.

20 This omission may be of little practical importance. It is of interest mainly as evidence of the survival of the old principle. 
tributors and thus to avoid control of retail prices. The effort to maintain competition between distributors, however, coupled with the great political pressure exerted by small distributors and their suppliers who are fearful of elimination, has resulted in severe modifications of the policy of controlling price differentials by reference to those likely under perfect price competition. Price competition between distributors might lead to the survival of a few large units. When the courts were earlier presented with this dilemma in the field of production they chose to pursue efficiency even if it resulted in the weakening of competitive forces in the market. Apparently Congress has chosen the other horn of the dilemma in dealing with the field of distribution. The Robinson-Patman Act contains provisions likely to handicap the development of large distributors. It rests, therefore, upon conflicting principles; it indicates the awkward consequences of efforts to preserve the prerequisites of competition; it admits the inadequacy of past efforts to preserve these prerequisites.

Discrimination has in general been prohibited under both the Clayton and Robinson-Patman Acts when the effect may be to lessen competition substantially or to tend to create a monopoly ${ }^{27}$ in any line of interstate commerce. ${ }^{28}$ These familiar phrases suggest an effort to continue the basic policy of the Sherman Law making clear its application to a specific practice. ${ }^{28}$ The prohibition of discrimination where it may lessen competition or tend to create a monopoly in any line of commerce indicates the presence of the new principle above mentioned, namely, the control of price differentials on the selling side of the market in the hope of maintaining the prerequisites of competition at least on the buying side and, therefore, in subsequent markets on the way to the ultimate buyer. This new principle was accepted by the courts only some fifteen years after the Clayton Act was passed and then in a case affecting discrimination between fabricators and not distributors. ${ }^{30}$

In the cases presented to the courts between IgI4 and I929 affecting the relations between manufacturers and the various classes of retailers the courts generally avoided interference with the policies of sellers and assumed that, having maintained competition between these sellers, the middlemen and the consumer had been protected. A purpose to maintain the old channels of trade was held to be illegal in

\footnotetext{
${ }^{27}$ However, the latter act has, as will be seen, amended the Clayton Act by extending its prohibitions to cover acts the effect of which is "to injure, destroy, or prevent competition," without reference to the substantiality of the effect upon competition or the creation of monopoly. Robinson-Patman Act, \$I(a).

2 This necessary restriction to interstate commerce is already producing a crop of difficulties in pending litigation under the latter act. It is claimed that scllers peddling goods from local branch houses are not engaged in interstate commerce. Cf. In Matter of Kraft Phenix Cheese Co., F. T. C. Docket 2935; In Matter of Anheuser Busch Co. F. T. C. Docket 2987. It is also claimed that differentials to retailers if they affect competition between them affect only intrastate commerce. Cf. In Matter of Bird \& Son,Inc. and Montgomery Ward \& Co., F. T. C: Docket 2937.

${ }^{2}$ Continuity with the Sherman Act cases is also evident in the provision in $\$ 3$ of the Robinson-Patman Act against local discrimination "for the purpose of destroying competition or eliminating a competitor in such part of the United States" and against selling goods "at unreasonably low prices for the purpose of destroying competition or eliminating a competitor." The continuity is verbal rather than one of principle, more particularly in the Robinson-Patman Act.

${ }^{30}$ American Can Co. v. Van Camp Packing Co., George Van Camp and Sons, 278 U. S. 245 (1929). See pp. 310-3I1, infra.
} 
1914. In the majority of subsequent cases, however, little or no emphasis has been placed upon this principle. The line between permissible and illegal discrimination has sometimes been drawn by reference to the legal forms of business organization. It was held, for instance, that a seller may refuse to sell to a cooperative of retailers at any price other than that charged to a single retailer. ${ }^{32} \mathrm{He}$ may, however, group together for discount purposes the stores in a chain in each locality, even though they require individual canvassing and delivery, and refuse to permit independent retailers to pool their orders for the purpose of calculating discounts. ${ }^{33}$

In some of these and other cases the court has refused to interfere with the price differentials of a seller on the ground that a seller is free to select his customers. ${ }^{84}$ The Clayton and Robinson-Patman Acts both explicitly preserve the right if it is exercised in bona fide transactions and not in restraint of trade. Of course in a competitive world sellers would be free to choose their own customers but they would be unable to choose on any basis other than the price offered. Where there were differences in the cost of different kinds of business there would be a tendency to a normal rate of return ${ }^{35}$ in each. Prices would, therefore, vary in accordance with differences in cost. The courts, presented with evidence that conditions had so changed that sellers found an opportunity to charge differentials not in accordance with the competitive pattern, replied that one of the minor prerequisites of competition must be maintained even though the major prerequisites were present only in diluted form. ${ }^{36}$

The effect of discrimination upon competition among buyers received serious attention from the courts ${ }^{37}$ in 1929 , when they interpreted the congressional phrase "in any line of commerce" in the conventional, and apparently obvious, sense to include competition between those engaged in subsequent processes. ${ }^{38}$ Manufac-

${ }^{a}$ Eastern States Retail Lumber Dealers Ass'n v. U. S., 234 U. S. 600 (1914). The Association had arranged for the reporting and circulation of the names of wholesalers who sold direct to builders and contractors. This activity was held to be illegal partly because of the element of conspiracy and partly because of its objective.

${ }^{82}$ Mennen Co. v. F. T. C., 288 Fed. 774 (C. C. A. 2d, I923), cert. denied, 262 U. S. 759 (1923).

$\approx$ F. T. C. v. National Biscuit Co., 299 Fed. 733 (C. C. A. 2d, 1924), cert. denied, 266 U. S. 613 (r924).

${ }^{\boldsymbol{a}}$ A producer of cereals discriminating against a chain store by refusing to sell to it at its carload rate was held not to have contravened the law. Great Atlantic and Pacific Tea Co. v. Cream of Wheat Co., 227 Fed. 46,49 (C. C. A. 2d, 19i5); F. T. C. v. National Biscuit Co., supra note 33. "Effective competition requires that merchants have freedom of action in conducting their own affairs." 299 Fed. at 740.

${ }^{2}$ Rates of profit that in the absence of changes in conditions of demand and supply vould induce no change in the amount of resources in any line of activity.

${ }^{23}$ The right of a buyer to choose his sources of merchandise has also been upheld. Raymond Bros. Clark \& Co. v. F. T. C., 263 U. S. 533 (1924). An individual wholesaler refused to buy from a seller who sold to chain stores at wholesale prices.

${ }^{87}$ In Mennen Co. v. F. T. C., 288 Fed. 774 (C. C. A. 2d, 1923), cert. denied, 262 U. S. 759, the court stated that it saw no evidence that "the public suffered injury or that competitors had reasonablo ground for complaint." The court admitted that discrimination by a manufacturer might lessen competition among his customers or potential customers but decided that Congress had not intended to prohibit this kind of restriction upon competition. Its cmphasis was upon the absence of any decline in competition between the manufacturer and others in the same line of business.

${ }^{\$}$ American Can Co. v. Van Camp Packing Co., George Van Camp and Sons, 278 U. S. 245 (rg29). $A$ can manufacturer had sold cans and leased a sealing machine to one customer at $20 \%$ below published 
turers were then placed in a very difficult position. Pressed by large buyers for special prices they feared suits for restraining competition between the large buyers and their rivals. Where was the line between a justified and an unjustified discrimination ? $^{39}$ The Robinson-Patman Act was intended in part to clarify the law on this subject. It emphasized however the application of the Act to the restriction of competition in subsequent markets by prohibiting discrimination also where it may "injure" or "destroy" competition with the person who knowingly grants or receives the discriminatory price or with the customers of either. ${ }^{40}$ In fact it extended the application of the law. Under the terms of the Clayton Act it had been necessary to show a lessening of competition in an entire line of commerce. ${ }^{41}$ This new clause prohibited discrimination resulting only in injury to competition.

The Clayton and Robinson-Patman laws do not prevent discrimination as such. A spark plug manufacturer who sold to an automobile manufacturer at less than cost with the object of creating a demand for replacement purposes which would be met at higher prices was held not to have contravened the law. ${ }^{42}$ Presumably the automobile manufacturer and the accessory dealer are not in the same line of commerce and, therefore, the rule in the Van Camp case ${ }^{43}$ would not affect this decision. The sale of lime at one price to farmers and another to chemical manufacturers would be untouched so long as the price is uniform to all farmers and to all chemical manufacturers. Sales of coal at one price to apartment operators and another to industrial buyers, sales of chemicals at one price to fertilizer manufacturers and others to other buyers, or of milk at one price to distributors of fluid milk and another to cheese manufacturers appear to fall in the same category. These policies do not injure competition in the restricted sense in which it is defined but they are evidence of wide departures from price competition. Such discriminations do not occur in a competitive market. Sellers sell at the highest price offered and are as indifferent to the use to which the product is to be put as they are to the girth measurement of buyers. Furthermore, in so far as the broad principle of competition has been approved because of its effect upon the utilization of resources, serious departures from this utilization occur when the seller finds it possible and profitable to restrict the activities of farmers while encouraging those of chemical manufacturers.

\footnotetext{
prices which were apparently charged to its rivals. The Supreme Court in response to a question propounded by a Circuit Court of Appeals decided that the Clayton Act did apply to discriminations the effect of which was to substantially lessen competition or tend to create a monopoly on the buying side of the market. This reversion to the words of the Clayton Act was reiterated (American Can Co. v. Ladoga Canning Co. 44 F. (2d) 763 (C. C. A. 7th, 1930), cert. denied, 282 U. S. 899 (193I)) and a company discriminated against was awarded triple damages. The contention that the discrimination was made in good faith and to meet competition because the manufacturer feared that the buyer would make his own cans was rejected.

These decisions also presented the problem of defining a line of business.

¿ Robinson-Patman Act, \$I (a).

a This requirement had proved an insuperable obstacle to prosecution in most cases.

as. S. Kresge Co. v. Champion Spark Plug Co., 3 F. (2d) 415 (C. C. A. 6th, 1925).

- Supra note 38 .
} 


\section{B. Policies of Control}

I. Differentials between the Prices of Goods of Different Quality.

In the Clayton Act differentials in prices were permitted if they were "on account of differences in the grade, quality or quantity." ${ }^{\text {"4 }}$ Whether the Act imposed any limit upon differences in price in these circumstances was never clarified. The Robinson-Patman Act narrows the scope of prohibition upon discrimination because it relates only to sales of goods "of like grade and quality." 45 The significance of this change depends upon the manner in which the courts define grade and quality. The definition is important although far from easy. If differences in brand name justify differences in price special brands may be made for each class of buyer and the manufacturer may combine the production of his own with private brands. But if, as is generally assumed, unis basis of differentiation is not allowed ${ }^{46}$ there may be a reorosn:-suion of production. The production of private brands may be concen-ated in firms not selling under their own brand name. Manufacturers with brand names of their own may be compelled to seek forceful methods of increasing the sales of their own brand to make up for the loss of manufacturing business for the owners of private brand names. Large buyers may be impelled to seek purchases of the whole output of some manufacturers; no charges of discrimination can then arise. ${ }^{47}$ These manufacturers, if they are in industries where relatively small scale production survives, may be placed in a position of complete dependence upon the single large buyer. Loss of the contract in any year would leave them without any business. Their power to protect themselves against such an eventuality depends very much upon the conditions prevailing in the industry and especially upon the existence of excess capacity.

Rejection of brands as a basis of discrimination may lead to a physical differentiation of products until their differences are sufficient for the courts to accept them as not of like grade and quality. Manufacturing costs may thus be raised. In the chemical industries it may be possible to make products offering similar utility but of different physical constitution. They may sell one to large buyers and another to smaller at price differentials giving considerable benefit to the large buyers. Sellers still have the right to select their own customers in bona fide transactions and not in restraint of trade.

2. Differentials between Prices for Different Quantities.

Differences in the cost of selling or transportation justified differences in price under the Clayton Act if they made only "due allowance" for such differences in cost. ${ }^{48}$ The Robinson-Patman Act includes in this type of restriction differences in cost due to differences in quantities sold. ${ }^{49}$ It permits differentials that make only

4Clayton Act, 52.

$\approx$ Robinson-Patman Act, $\$$ I (a).

es Differences due to the cost of advertising their own brands would appear to be permissible. See p. 314, infra.

${ }^{4}$ Cf. Hearings before the House Committee on the Judiciary on H. R. 8442, H. R. 4995, H. R. 5062 (Amendment of Clayton Act) 74th Cong., Ist Sess. (1935), p. rg.

- Clajoron Act, 52.

Robinson-Patman Act, 5 I (a). 
due allowance for differences in the cost of manufacture sale or delivery resulting from the differing methods or quantities ${ }^{50}$ by which such commodities are sold or delivered. The most notable aspect of this provision is that it apparently permits a manufacturer to refuse discounts equal to differences in cost arising out of differences in quantity sold or methods of sale. ${ }^{51}$ If, as is likely, the Act is so interpreted it cannot be defended as a means of achieving in the sale of manufactured goods the results of competition. Sellers may discriminate in favor of but not against the firms with whom dealing is more costly. Such a policy cannot be defended on the ground that the law is being modified merely to remove the unfair advantages of large firms.

This same of policy permitting discrimination against large buyers appears to be implied in the provision in the Robinson-Patman Act permitting government control of price differentials. ${ }^{51^{2}}$ The introduction of direct control is itself notable as representing a shift toward direct control of price policy. Where the Federal Trade Commission finds that "available purchasers in greater quantities" of particular commodities or classes of commodities "are so few as to render differentials on account thereof unjustly discriminatory or promotive of monopoly ${ }^{52}$ in any line of commerce" the Commission may "after due investigation and hearing of all interested parties, fix and establish quantity limits and revise the same as it finds necessary." But under what circumstances would differentials making "due allowance" for differences in quantity purchased be unjustly discriminatory? If the differentials do not exceed the differences in cost referred to above why interfere merely because only a few firms can qualify for them? The second ruling phrase is "promotive of monopoly." Here again the legislature was face to face with the inconvenient tendency of an individualism that encourages the survival of the fittest to destroy, by that very fact, the mechanism for the future selection of the fittest. In giving to the Commission power to fix maximum discounts under these conditions an attempt is made to limit the size of firms in the distributing industry so as to prevent the emergence of monopoly, however that may be defined. The power is given apparently in defiance of the possibility that the large firm is increasing in size because of its superior efficiency. Congress seeks to modify the dictum of the Supreme Court that "the law does not make mere size an offense"53 by adding "except in the field of distribution." Regulation of the size of firms by way of the regulation of the prices they pay for their materials can, of course, be a far more powerful means of control in the field of distribution than in the field of manufacturing. What size

\footnotetext{
${ }^{\infty}$ Sellers customarily classify their buyers into a few groups for the purpose of calculating discounts. Even where they are classified according to the size of orders there is some discrimination. It is doubtful, however, whether the courts will insist on separate prices for orders of each size.

at Hearings, supra note 47 , p. Io. Vo Robinson-Patman Act, \$I (a).

"The standard, "unjustly discriminatory or promotive of monopoly," may be held to be so lacking in precision and definiteness as to render the provision an unconstitutional delegation of legislative power if the Court continues to utilize the principle-apparently discovered in the "hot oil" case (Panama Refining Co. v. Ryan, 293 U. S. 388 (1935)).
}

U. S. v. U. S. Steel Corp., 25 I U. S. 4 I77, 451 (1920). 
of firm will be the maximum permissible? When the Supreme Court has sought to restore competition by partitioning large firms held to be in breach of the law it has substituted in some cases three or four firms. Will the Commission be guided in the administration of this uncomfortable power by the precedent set by the Court, and how much protection will the consumer thereby secure? Can sellers whose opportunities for increasing their relative volume of business are cut off by Congress be regarded as vigorously competing with each other to the benefit of the buyer?

3. Differentials due to Differences in the Cost of Selling.

The allowance of price differentials to cover differences in the cost of selling will presumably recognize advertising costs as a justification for differentials. Neither the Congress nor the courts have taken action to curtail expenditure upon advertising although, as is explained above, such expenditures are in large part a substitute for price competition as a way of obtaining business. They seriously interfere with competition in the market and tend to raise costs.

4. Differentials "to Meet Competition."

Discrimination in good faith and to meet competition was permitted in the Clayton Act ${ }^{54}$ and the Robinson-Patman Act makes little change in this respect. ${ }^{\text {b5 }}$ This provision implies the possibility that discrimination may occur in defiance of the law and permits others to follow suit if some seller has started it. This attitude may be realistic but it creates difficulties. May a seller discriminate when he honestly believes he is responding to a similar policy on the part of a rival? Moreover the patterns of discrimination existing on the day the law came into force can all be defended by individual sellers under this clause. So long as these price differentials are unchanged they may be beyond the reach of the law. ${ }^{66}$ If a seller supplies superior facilities rivals may respond with a lower price. ${ }^{57}$ It would appear to be necessary, therefore, to determine how much difference between the prices of competitors may be justified by any difference of facilities.

\section{Discrimination and Changes in Price.}

The Robinson-Patman Act introduces a new provision that the Act shall not prevent price changes from time to time in response to "changing conditions affecting the market for, or the marketability of, the goods concerned." ${ }^{8}$ Sellers faced with the deterioration of goods, obsolescence of seasonal goods, or those discontinuing business may make price reductions without breach of the law. Congress was

* Clayton Act, 52 .

ETe Act, $\$ \mathrm{I}(\mathrm{b})$, provides that any seller may rebut a prima facie case of illegal discrimination by showing that "his lower price or the furnishing of facilities or services to any purchaser or purchasers was made in good faith to meet an equally low price of a competitor or the services or facilities furnished by a competitor."

${ }^{t e}$ The Act may have the effect of permitting differentials in excess of cost differentials. If one firm can show cost differentials justifying certain discounts others may apparently grant the discounts without being able to achieve the economies on which they are based.

"Ef. Answer to Complaint, In Matter of Shefford Cheese Co., F. T. C. Docket 2936. The Company defended part of its discounts on the ground that it did not deliver at the store door while its rivals did.

* Robinson-Patman Act, SI(a). 
probably fearful that prices might be reduced for a short time to accept a large order and subsequently raised again. But if prices charged at different times are to be compared serious problems are likely to occur. How long a period of time is to be taken? Ultimately this question leads to the necessity of deciding what "changing conditions affecting the market" justify a price change and how large a change they justify. ${ }^{59}$ At this point apparently the policy has been transformed into one of price control.

\section{Differentials in Services or Allowances.}

The Robinson-Patman Act seeks to deal with some of the possible discriminations in matters other than price but having similar effects. It was alleged that large distributors had benefitted from advertising and brokerage allowances. ${ }^{60}$ The large distributors explained that it would be uneconomical to make them purchase through brokers whose services they did not need, and whose charges would be added to their costs. ${ }^{\mathrm{c} 1}$ Such a policy would merely protect antiquated methods of distribuion. Brolierage payments of this kind were, nevertheless, prohibited. ${ }^{62}$ This clause, however, merely prevents large buyers from obtaining part of the economies of their size in the form of fictional brokerage payments. They must seek them all in the form of price differences which must meet the requirements already laid down.

Advertising allowances were defended by the large sellers as a modern method of promoting sales. ${ }^{63}$ One large chain was reported to have received advertising allowances from one manufacturer amounting to eight million dollars in one year, of which six million dollars are said to have been spent by the buyer on advertising. ${ }^{64}$ Allowances had also been made for window dressing although they had not necessarily been so applied. ${ }^{65}$ The Act does not forbid such allowances or limit them to the cost of advertising service rendered by buyers; it merely requires that they shall be made upon a "proportionally equal" basis to all buyers. ${ }^{B 6}$ It gives no indication of the basis of calculating proportionality. ${ }^{67}$

${ }^{5} \mathrm{Cf}$. Answer to Complaint, In Matter of Bird \& Son, Inc. and Montgomery Ward \& Co., F. T. C. Docket 2937. Montgomery Ward denied knowledge whether the sellet's price changes had been made in good faith in response to changing conditions in the market.

${ }^{\infty}$ Hearings, supra note 47, pp. $6,6 g, 96,183$. $\quad$ Id. at Pp. 148,184 .

${ }^{62}$ The Act, $\$ \mathrm{I}(\mathrm{c})$, malies it illegal to grant or accept anything of value as a commission, brokerage or allowance except for services rendered in connection with the sale or purchase. Brokerage payments may not be made to intermediaries unless they are under the control of the person paying the commission.

Hearings, supra note 47 , at pp. 149, 177. See also charges of payments of advertising allowances by razor blade manuIacturers contended by the Fedcral Trade Commission to be in violation of $\$ 2$ of the Clayton Act. N. 1'. Times, April 21, 1936, p. 47. Hearings, supra note 47, at p. 61.

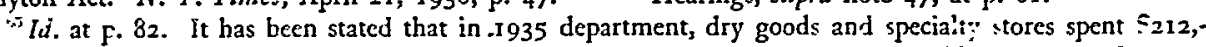
ono.cno for general publicity, of which $\$ 136,000,000$ was spent for newspaper pub!: ty. Manufacturers are sisid to have contributed about $\$ 5,000,000$ towards the cost of this publicity. N. Y. Times, Aug. 16, $1930, \$ 3, \mathrm{p} .8$.

"The Act, $\S I(d)$, forbids paynents by a seller for the benefit of a customer as compensation for facilitic: or services furnished by the eustomer in connection with the processing, handling or sale unless such a consideration is made available "on proportionately equal terms to all sther customers competing in the distribution of such products."

"Some distributors, after temporarily äbandoning advertising allowances, are reported again to have 


\section{The Effects of Control}

I. Upon the Organization of Distribution.

The effect of the Robinson-Patman Act upon the struggle between the competing types of distributor depends partly upon the policy of the Federal Trade Commission in fixing maximum discounts and the attitude of the courts to its policy. Upon this subject there is little to say. So far as discounts may be allowed up to the differences in the cost of dealing with different types of distributors the pressures will probably be similar to those affecting resale price maintenance and there will be a tendency for manufacturers to favor the small distributors, subject, however, to important checks already mentioned. So far as large distributors secure the full benefits of the economies of their method of distributing their discounts will depend upon the amount of the economies involved. In the first place, there will be general pressure upon manufacturers to calculate costs in order to have evidence on this subject. This pressure will reveal the arbitrariness of many conventional allocations of costs. It is not inconceivable that it will be found in some cases that the large buyers have been "carrying" the smaller, i.e., that larger discounts could be given to the larger firms without contravening the law. Discounts based upon the contention that a single large order raises the rate of operation of plant more than a small order appear to have been regarded in Congress ${ }^{68}$ as undesirable. In so far as the loss of a large order necessitates obtaining a number of small orders in order to maintain the rate of operation, and the cost of obtaining these small orders may be higher than that of obtaining the large order, differences in price would be justified by differences in the cost of selling. But, as a number of small orders can raise the rate of operation as effectively as a large one of an amount equal to the aggregate of the small orders, the manufacturing costs in the one case are the same as in the other. Neither the large nor the small orders can legitimately be singled out to bear the burden of the initial costs of running the plant at all.

Large orders for future delivery may well justify lower prices. If they permit production during "off peak" periods they may enable a plant to maintain an average rate of operation over a period of time higher than would otherwise be possible. The total amount of resources necessary to produce a given total output is less when the plant is operated regularly than when it is operated irregularly ${ }^{69}$

demanded them but to haye required in their purchase contracts an avowal that the manufacturer is prepared to make similar arrangements with other purchasers similarly situated and on proportionately equal terms. While the buyer, as, well as the seller, is responsible for any breach of this clause the buyer can know whether breach has been committed only if he knows the prices charged by the sellers to all his rivals and also the meaning of the phrase "proportionally equal." The avowal demanded of the seller is sought as a means of defense in this difficult situation. N. Y. Times, Aug. 27, 1936, p. 37. The position of advertising allowances made in an entirely separate contract is dubious.

${ }^{a}$ Hearings, supra note 47 , p. xo.

- The Federal Trade Commission complained that the Goodyear Tire and Rubber Company had discriminated in favor of a large mail order house in contravention of the Clayton Act. The contract with the mail order house provided for a large minimum annual purchase of tires over a period of years. These tires were sold by the mail order house under its own brand names. Those sold to dealers were sold under the manufacturer's brand which he advertised. Until wide publicity was given by the Federal 
yet the resulting economies fall to those able to give large orders and the large distributors may continue to obtain better prices than do smaller buyers. ${ }^{70}$ The social advantages of this method of organizing production are undeniable although its consequences in terms of the survival of a small number of large distributors may be disliked. Discounts based merely upon the total amount of purchases during a given period would, however, be difficult to justify. If the large buyer purchases upon a hand-to-mouth basis his demands may be as spasmodic as those of small buyers and occur at the same time.

2. Effects upon the Price Policies of Manufacturers.

The policy of controlling discrimination may affect the general level of prices charged by manufacturers. The law appears to hamper if not abolish secret price cutting. A sale to one buyer at less than the "regular" price could be argued to injure the competition between rivals who paid the regular price and the buyer at the cut price. Such price cutting may not be defensible in terms of differences in the cost of manufacture or delivery. It does not necessarily favor the largest buyers. Where manufacturers are relatively few, and overhead costs an important part of total costs, there is constantly anxiety to prevent secret price cutting. Secret price cutting by one seller causes rivals to lose business and they resort to similar price cuts. The market becomes "chaotic" in the sense that there is no uniformity of prices and a price war is likely. On the other hand, a manufacturer carrying overhead costs is often tempted to obtain business by making a secret concession from his regular price. An open reduction involves a loss of revenue upon all his other business and this loss may exceed the beneficial effect of the additional business, allowance being made for the out-of-pocket costs of executing the order. But if the concession is made upon one or a few orders the gain may exceed the out-ofpocket cost of the business. There is no economy in a policy of throwing industry into price wars and little possibility of doing so. But the importance of secret price cuts lies in their tendency to operate as an entering wedge for open price reductions.

Trade Commission, the majority of purchasers were doubtless unaware of the origin of the tires of the mail order house. The Commission ordered the discontinuance of discrimination "by selling at net realized prices which are lower than the net realized prices at which it sells tires of comparable grade and quality to retail dealers and other customers." Matter of Goodyear Tire and Rubber Co., F. T. C. Docket 2116 (1936) The Commission claimed that the discrimination made more than due allowance for the cost of selling or transportation and was not made on account of differences in grade quality or quantity sold. It emphasized that the discrimination had been kept secret from other purchasers from the manufacturer, thus suggesting doubt as to whether they represented only the cenomies resulting from tive scale of the purchare. Competition had been substantially restrained between the mail order houses ind other distributors of tires, and the contract tended to create a monopoly in the distribution of tires. In its order, bewever, it ignored differences in the cost of manufacturing or of selling as well as differences in quantity as justifying price differentials. The Company announced the abrogation of the contract on account of the parsage of the Robinson-Patman Act. It also announced that it would appeal from the decision of the Commissiun concerning its operations prior to the clange in law, N. Y. Times, July 17, 1936, p. 30.

${ }^{\pi}$ Chains often buy farther ahead than do small buyers. Hearings, supra note $47, \mathrm{pp} .23,24$. As large buyers buy for longer future delivery than the small the price charged on the day of the contract for immediate delivery to small buyers may be more than that for future delivery for large buyers. Similarly the price on the day of delivery may differ between the two classes. 
In imperfectly competitive markets they indicate an imperfect foresight of sellers which supplies a downward pressure on prices. If secret price cutting is eliminated sellers act upon the assumption that any reduction in price made by them will be immediately met by all rivals. They think in terms of the total demand at each price, i.e., as a monopolist, although possibly limited by the fear of new competition resulting either in a cutting of prices or a wider sharing of the market at existing prices. The sellers draw the line between a desirable and an undesirable price cut but their standards of desirability frequently depart from the general social interest. The elimination of secret price cutting, therefore, increases the imperfection of competition.

Downward pressures upon prices are also reduced by attempts to obstruct large buyers who are said to beat down the prices of manufacturers without mercy. Mercy of course found no place in the freely competitive market. How low can prices be forced? It may be said that the large order is a great temptation to the seller. Why? If it is because it saves the cost of obtaining a large number of small orders the Act does not remove the temptation. But a manufacturer may accept a low price because he has become dependent upon the large buyer; he may have allowed his selling organization to shrink and have relied upon continued orders from the large firm. Turning to small orders means incurring the initial costs of entering an alternative market. But this situation may even be encouraged under the law because a manufacturer selling his whole output to a single buyer is immune from the Act. The large buyer may obtain low prices because of the low rate at which capacity is being operated in the manufacturing industry. Any price above the out-of-pocket costs of new business yields a contribution towards overhead costs. The prospect of a large block of business promises a large aggregate contribution, although the contribution per unit of output may be low. In the absence of pressure from large buyers manufacturers in many industries where overhead costs are important have shown a preference for meeting a decline in demand by maintaining prices and allowing output to fall. The quantitative amount of the fall in output due to the maintenance of prices varies of course from industry to industry. and with the period of time in view. In so far as plants not used become obsolescent, rust out, involve costs for maintenance or increased interest charges, additional costs are imposed on the industry and upon society without corresponding benefit. The large buyer may, therefore, be a means of overpowering the sellers and preventing them from pursuing this policy. At the present stage in the evolution of distribution and prior to the passage of the Robinson-Patman Act there was probably vigorous enough rivalry between distributors to ensure that the benefits of these downward pressures upon prices were passed on to ultimate purchasers. There looms in the future, however, the possibility that distributors may become so large and so few that the pressure to pass on these benefits may be seriously modified.

These problems are particularly acute in times of depression. Freedom to large 
distributors to press down manufacturers as far as they are able may cause the elimination of firms. Productive resources which society would have been well advised to keep in use in order to meet a later increase in general demand may be abandoned. Their abandonment necessitates the investment of new capital when the upturn of business comes, possibly stimulating the upswing of general business activity. This situation is extremely complex and the analysis necessary to provide a basis for a proper policy is not available. In the first place the pressing down of prices, if general, may restrict the depth of the downward swing in industrial activity and indirectly reduce the prospect of the elimination of firms. In the second place, the failure of firms does not always involve the abandonment of plant. It may continue in production with a lower capitalization. In the third place it is always difficult to determine the amount of investment that should be retained in an industry to meet the upturn of business. The amount and time of the upturn are always uncertain. The obstruction of the development of large distributors and the elimination of secret price cutting is likely, however, to have the general effect of strengthening manufacturers in their efforts to maintain prices, thus reducing output and possibly intensifying depression.

\section{Conclusion}

It is abundantly evident that the policy of maintaining the prerequisites of competition, either in the narrow theoretical sense or even in a somewhat broader interpretation, has failed to attain its objective. If mere unfairness in the policies of the large firms ${ }^{71}$ is the explanation of the decline of price competition, the modifications that have been introduced into the law by the anti-trust laws have until now failed to maintain competitive markets in many industries. The more plausible explanation of the increasing imperfection of competition is that it is due to changes in the techniques of production and selling. In some of the branches of heavy industry the economies of large scale production, coupled with the fact that markets are narrower than the national boundaries are sufficient to explain the imperfections of competition.

In choosing whether to maintain the number of firms at a competitive level or to accept the economies of size and with them a decreasing number of firms, the courts have in general chosen the latter alternative. In the sale of consumers goods the other major change accounting for the size of firms lies in the development of methods of sales promotion. Neither the courts nor Congress have adequately. recognized the tendency of this development to damage the market by dividing it into a series of sub-markets for specially branded products. Even when contemplating the policies of sellers powerful enough to seek to maintain resale prices, and

\footnotetext{
7t The pursuit of profit is sometimes the basis of criticism of large firms, although such conduct is of the essence of capitalism. An important aspect of price policy in the steel industry has been condemned as " 2 network of actions by individuals and groups motivated by the desire for larger profits and acting without regard for the interests of other industries or the consuming public." Fetter, Planning for Totalitarian Monopoly (1937) 45 J. Poz. EcoN. 102.
} 
thereby restrict-price competition in later markets, or to set discounts favoring one class of distributor rather than another, the courts failed to be impressed by the extent to which such sellers have been emancipated from competitive pressures. The courts have looked back to the picture of a competitive world and refused to interfere because the seller must have power to select his customers, or even for more formal reasons. In its recent legislation Congress appears to endorse price differentials allowing the seller to seek to recover the cost of advertising his goods. To do otherwise would undoubtedly cause serious dislocation of business but to proceed thus is not to maintain the prerequisites of competition. States have enacted resale price maintenance legislation which will have similar effects.

In the threefold struggle that has developed between the sellers of advertised goods, the small scale distributors and the large scale distributors, federal and state governments have been under pressure to obstruct the development of large distributors. Those threatened with ejection from their positions in the market and in part also manufacturers seeking to maintain powerful positions by advertising, have exerted great pressure. They have not sought to eliminate only the unfair advantages of large distributors. Taxes against chain stores are an obstacle to one kind of large scale distribution arbitrary in amount. Progressive taxes on gross sales also hamper large firms. The bias against large distributors in the Robinson-Patman Act has already been mentioned. Thus, although anti-trust laws have failed to maintain the numbers of manufacturers there appears now to be an effort to restrict concentration in distribution, a process of relatively recent occurrence. But in the process of doing so not only is the pursuit of the economies of large scale distribution hindered. Price competition between manufacturers is softened and they exercise control over the reorganization of distribution.

The type of case coming before the courts and the situations with which Congress endeavors to deal all suggest how far competition has receded in a number of markets. Efforts to rearrange the scenery so that competition could commence and continue would involve far reaching changes likely to induce drastic opposition from business and the courts and to offer the ultimate purchaser little if any benefit. In fact the control of price differentials is a step in the direction of a policy of seeking the ends of competition by social control. This policy leads on toward increasing state control. Maintaining the number of distributors beyond the economical number does not give the buyer the benefits of competition. The difficulties and dangers of control of prices are difficult to exaggerate. There may be ways of permitting a wide decentralization of economic initiative and yet securing the orientation of the economic system toward reasonably acceptable social objectives and its reasonably efficient operation. Unless such policies are speedily discovered we face the mountainous problems of price control. 